\title{
HOW MANY LEGAL SYSTEMS?: SOME PUZZLES REGARDING THE IDENTITY CONDITIONS OF, AND RELATIONS BETWEEN, LEGAL SYSTEMS IN THE EUROPEAN UNION
}

\author{
Julie DiCKSON*
}

\begin{abstract}
Resumen:
Este artículo discute varios modos posibles de comprender el carácter de los sistemas jurídicos de la Unión Europea y sus relaciones. En particular, se plantea la cuestión de si existe un sistema jurídico en la Unión Europea adicional y distinto del sistema jurídico nacional de los Estados miembros; o si es mejor concebir el derecho de la Unión Europea simplemente como un aspecto de los sistemas jurídicos de los Estados miembros; o bien, si es que deberíamos pensar que no hay sino sólo un sistema jurídico en la Unión Europea con respecto del cual los "sistemas jurídicos nacionales" de los Estados miembros son en cierta forma subsistemas.
\end{abstract}

Abstract:

In this article I discuss various possible ways of understanding the character of and relations between legal systems in the European Union. In parti-

* Fellow and Tutor in Law, Somerville College, University of Oxford; julie.dickson@law.ox.ac.uk. Much of the research for this article was conducted during my time as a Visiting Fellow in the Faculty of Law, University of New South Wales, Sydney, Australia, in April to June 2007. I am grateful to Somerville College for sabbatical leave, and to the Law Faculty of the University of New South Wales for use of their research facilities, and also for their friendliness and hospitality. I am also grateful to those who participated in the staff seminar which I gave based on this paper at UNSW in May 2007 and in the Special Workshop on Legality's Edges at the 2007 IVR conference in Kraków, and to Keith Culver, Mike Giuduce, Jan Komárek, Malcolm Ross, Juan Vega Gómez, Steve Weatherill and Alison Young for thought-provoking comments and discussion. 


\section{JULIE DICKSON}

cular, I consider whether there is an EU legal system distinct from and in addition to the national legal systems of EU Member States, or whether it is better to conceive of EU law merely as an aspect of Member States' legal systems, or indeed whether we should think of there being but a single EU legal system of which Member States' "national legal systems" are in some sense sub-systems. 
SUMMARY: 1. Introduction. 2. Is There an EU Legal System? 3. The Relevance of Rival Supremacy Claims. 4. Direct Effect and Supremacy: Whose Norms are They Anyway?. 5. Conclusion and Future Issues: Further Complexities and Recent Developments in the Relationship Between the EU Legal System and Member States Legal Systems.

\section{INTRODUCTION}

How many legal systems are there in the European Union? Interpreted as a question about the legal systems of the Union's constituent Member States at a given moment in time, this may seem like an easy question: October 2007, twentyseven Member States, twenty-seven legal systems. Even interpreted this way, however, this apparent simplicity evaporates on closer inspection, for there are Member States which appear to be multi-legal system states, such as the United Kingdom, which arguably brings to EU membership not one legal system but three. ${ }^{1}$ In the present article, however, I am concerned not merely with the legal systems of each of the EU's Member States, but also with the existence and character of the EU legal system itself, and with its relations with the legal systems of Member States. Does there exist a European Union legal system, which can be understood as in some sense distinct from and in addition to those legal systems of the EU's constituent Member States, and with a separate relationship with each of those Member State legal systems? (We might call this the "Distinct EU legal system" model or, ignoring the possibility of multi-legal system Member States for the sake of simplification of terminology, the "27 plus 1" model). Is EU law merely to be understood as an aspect of each of the legal systems of the Member States (for example, to the extent that its norms are enforceable in Member States' courts), and not as a distinct entity in addition to those domestic legal systems? (We

1 The legal systems of Scotland, Northern Ireland, and England and Wales respectively. I cannot explore or defend this claim here. 
might term this the "Part of Member States' Legal Systems" model). Or, more radically (at least in terms of practical politics and the popular media in some Member States), with regard to areas falling within the competence of the European Union, is there only one EU legal system, of which the constituent Member States' legal systems are to be understood as (in some sense) subordinate sub-systems?2 (The "One Big Legal System" model). Even this introductory attempt to pose these questions is beset with ambiguities and raises yet more questions at every turn as regards the possible relations between EU law and national law. ${ }^{3}$ Moreover, the present article does not attempt to settle these issues conclusively. Rather, my aim is a more preliminary one: that of attempting to bring the relevant questions more clearly into focus, and to explore some considerations stemming both from general jurisprudential understandings of the nature of law and legal systems, and from particular examples of EU legal doctrine, which in my view are relevant to building a sound understanding of the character of and relations between legal systems in the European Union. ${ }^{4}$

2 In the present article I use the terms "EU law" and "EU legal system" in a broad non-technical sense, $i$. e. not to denote those distinctions which remain between the so-called three pillars of the EU. In fact, however, the particular examples of EU legal doctrine I discuss are drawn from the Community "pillar", and are hence instances of European Community law (to the extent that three distinct pillars and concomitant bodies of law can still be identified). This being so, depending on the context, I sometimes refer to "EC law" and to "EC rights" when discussing particular examples. Although I do not focus in this article on the remaining differences between the pillars in terms of the relations between the EU legal system(s?) and Member State legal systems, as will emerge during the course of the discussion, I suspect that there cannot be a one-size-fits-all answer to the question of the relationship between the EU legal system and national legal systems because any such answers are in part dependent on the differential extent and manner of enforceability in domestic courts of various types of EU norms.

3 The possibilities canvassed above are not intended to be exhaustive, and also do not mention, for example, the relationship between EU law and international law (or the relations between EU law, national law and international law). My aim is rather to convey a flavour of the kinds of questions which have prompted my interest in this topic in terms of the present article.

4 N.b. this is not to say that I regard questions concerning the proper way to understand the relations between legal systems in the EU as unresolvable or that it is futile to search for the truth of the matter in respect of them. In this respect, my approach differs from that taken by Catherine Richmond in her careful and il- 
Extensive work on these and related issues has, of course, been undertaken by European legal scholars, perhaps especially in the context of trying to make sense of and draw conclusions from the rival claims to legal supremacy made by the European Court of Justice, and some Member States' constitutional courts respectively. ${ }^{5}$ However, in common with Neil MacCormick and Mattias Kumm, I regard some of that work as inadequately theorised. ${ }^{6}$ This being so, what I hope is distinctive about my approach in the present article is that it attempts to examine those issues outlined above in light of some jurisprudential work regarding the nature of legal systems, and that it takes the question of how to think about the legal systems of the EU given the complex interrelations between EU norms and EU Member States' national norms as its central concern.

A word on method: in previous work I advocated a methodological approach wherein law's essential properties can and should be identified and explained without yet taking a stance on their moral or political worth or justifiability, or on what we should do about law (e. g. obey, disobey, attempt to dismantle, or to reform it) given its nature and the demands it makes on us. ${ }^{7}$ This methodological approach

luminating article, "Preserving the Identity Crisis: Autonomy, System and Sovereignty in European Law", 16 Law and Philosophy (1997), 377-420. Richmond contends that there is a plurality of different ways of understanding the relationship between EU law, national law and international law, and that the approach she adopts, “...makes no claim to be derived from or to reflect actual practice or empirical 'reality' in the Community" (op. cit. at 381), apparently on the grounds that, in such a young legal system, there is no settled "institutional reality" (p382) to be captured accurately.

5 I discuss this particular issue, and the work of some commentators on it, in section 3 below.

6 See N. MacCormick, “Juridical Pluralism and the Risk of Constitutional Conflict”, in MacCormick, N., Questioning Sovereignty (Oxford University Press, 1999), ch. 7, especially at 102 and 105; Kumm, M., "The Jurisprudence of Constitutional Conflict: Constitutional Supremacy in Europe before and after the Constitutional Treaty", 11 European Law Journal (2005), 262-307, especially at 267-8 and 306.

7 See J. Dickson, Evaluation and Legal Theory (Hart Publishing, 2001). The following remarks on methodology are necessarily brief and do not capture the subtlety and complexity of the debate. 
informs the present study as well: my primary aim is to work towards a better understanding of the character of and relations between legal systems in the EU, not to explore the moral or political legitimacy of those relations, nor to attempt to provide guidance to the European Court of Justice or Member States' courts as to what they should do when faced with adjudicative dilemmas resulting from, for example, rival supremacy claims or other conflicts of norms between EU legal systems. Some EU constitutional scholars appear to criticise such an explanatory approach for its "normative inertness", 8 i. e. precisely because it will not tell judges what to do in resolving conflicts which may arise between, for example, a national constitutional court and the ECJ. ${ }^{9}$ This is true, but, in my view, not a cause for criticism. The goal of attempting to understand what something

8 I borrow this term from John Gardner in, "Legal Positivism: 5 1/2 Myths", 46 American Journal of Jurisprudence (2001), 199-227 at 203.

9 This is my understanding of Mattias Kumm's views on the inadequacy of understanding rival supremacy claims of the EU legal order and Member States legal orders in terms of a conflict between two distinct ultimate legal rules determining what is to count as law (e. g. Hartian rules of recognition) in Kumm, M., "The Jurisprudence of Constitutional Conflict: Constitutional Supremacy in Europe before and after the Constitutional Treaty", n. above, especially section II. However, Kumm's methodological stance in this article is in fact not entirely clear. He begins the article (p. 266) by distinguishing between descriptive, explanatory and normative accounts of the relationship between EU law and national law. At this stage, he appears to regard the former two approaches as valuable in their own right, albeit distinct from the third approach, which he wishes to pursue himself and which he characterises as exploring, "the normative question what national courts should be doing..." (p. 266). However, he then criticises (section II, especially 273-4) attempts to understand the rival supremacy claims of the EU and national legal orders in terms of a conflict between ultimate legal rules on the basis that such accounts explain such rival claims in terms of the existence of two incompatible ultimate legal rules - of the EU legal order, and of a given national legal order- and are then committed to the view that legally speaking there is no way to resolve the conflict, and so do not provide legal or other guidance as to what a court faced with two incompatible such rules should actually do in a case before it. This, however, appears to criticise an explanatory account of the nature of ultimate legal rules and their role in legal systems in identifying what is to count as law, for failing to answer the normative question of what a judge ought to do if faced with two conflicting such rules. This latter question, however, is not a question which an account of the nature and role of ultimate legal rules (such as Hart's or Kelsen's, both of whom Kumm mentions in his article) were intended to answer. All of this seems to sit awkwardly with Kumm's earlier acknowledgement of the distinctness and value of descriptive and explanatory accounts of legal phenomena. 
is like for its own sake, surely on any view a centrally important aim of academic activity, seems to me to have been improperly demoted by some legal theorists, on the ground that only accounts of law which tell us which justifying values underlie it and hence which course of action is mandated in light of it are sufficiently "interesting" to be the proper province of jurisprudential theorising. ${ }^{10}$ I regard legal theory as a broader church than this, and one in which we should not apologise for having the aim of deepening our understanding of some aspect of law rather than working out what a judge or court or citizen ought to do. Achieving an accurate understanding of the character and complexity of relations between legal systems in the EU seems an interesting and important task especially given the relevance of the EU and other international organisations in contemporary social and legal life. Such an understanding may of course be an important precursor to a consideration of the present and potential future political legitimacy of the EU, and may point the way towards the proper way to resolve adjudicative and other conflicts arising in the EU legal systems (both extremely important and worthwhile theoretical projects) but on the methodological approach adopted here, the chances of moving forward with such projects in a sound way will be enhanced by attempting first of all to understand the character of the EU, and the relations between its legal systems.

All this said, however, it is also my view in the present article that some issues regarding the limits of and relations between the EU legal system and Member States legal systems can only be approached by considering the particular character of the EU and the political context in which

10 I am thinking in particular of Dworkin's, R., "Hart's Postscript and the Character of Political Philosophy", 24 Oxford Journal of Legal Studies (2004), 1-37, especially the final section, at 35-7 (a revised version of this piece now appears in Dworkin, R., Justice in Robes (Harvard University Press, 2006, as chapter six). The characterisation of his own brand of jurisprudential theorising as "interesting" in contrast to what he refers to as "descriptive or conceptual" legal philosophy is Dworkin's. See also Dworkin, R., "Thirty Years On”, 115 Harvard Law Review (2002), 1655-1687, especially at 1678-81. 
it exists, and the particular legal and constitutional doctrines developed within it over the last fifty years. In the context of the EU, some questions regarding the identity conditions of legal systems, and, in particular, whether a given set of norms are best thought of as belonging to one legal system or another may not be answerable purely by reference to abstract theoretical considerations regarding the nature of legal systems and their criteria of system membership. This being so, the general methodological approach outlined above may need to be tempered somewhat in order to improve our understanding of the relations between legal systems in the particular context of the European Union. This point should become clearer as the article progresses and as I start to consider what sort of investigations might be necessary in order to develop a fuller understanding of the issues outlined above.

\section{Is There AN EU Legal System?}

What evidence is there for the existence of an EU legal system which is distinct from the legal systems of the EU's constituent Member States, with its own criteria of system membership determining which laws are part of that system, and the manner and extent of their enforceability? On the face of it, plenty. First of all, we have the many pronouncements of the European Court of Justice on the matter - so familiar as to now seem commonplace- in a seminal line of cases spelling out its view of the character of the EU legal order and its relationship with Member States' legal orders and Member States' nationals:

...the community constitutes a new legal order of international law...11

By contrast with ordinary international treaties, the EEC treaty has created its own legal system... ${ }^{12}$ 
...the law stemming from the treaty, an independent source of law...13

The transfer by the states from their domestic legal system to the community legal system of the rights and obligations arising under the Treaty... ${ }^{14}$

It should be borne in mind at the outset that the EEC Treaty has created its own legal system... ${ }^{15}$

The EU is also endowed with its own sources of law, ${ }^{16}$ law-making institutions and procedures, ${ }^{17}$ methods of policing Member States' compliance with EU obligations, 18 procedures for the judicial review of EU norms, ${ }^{19}$ and, largely thanks to the renowned judicial activism of the ECJ, its own distinctive take on doctrines regarding the direct enforceability of EC law by individuals in Member States' courts, ${ }^{20}$ and its primacy over national law in cases of conflict. ${ }^{21}$ Perhaps the doctrine of the primacy or su-

13 Ibidem, at 594.

14 Idem.

15 Joined Cases C-6/90 \& C-9/90 Francovich and Bonifaci $v$. Italy [1991]ECR I-5357 at para. 31 .

16 In the form of the constitutive Treaties of the EU, as amended, secondary legislation created and agreements made thereunder, recognised general principles of law including fundamental rights, and judicial decisions of the European Court of Justice and Court of First Instance (although there is formal system of precedent in respect of these latter).

17 Arts. 189-267, Treaty Establishing the European Community (hereinafter EC Treaty).

18 Arts. 226-8 EC Treaty, and also the "individual enforcement" methods under the direct effect, indirect effect, incidental or exclusionary effect, fundamental rights, and Member State liability lines of case law, discussed further in the remainder of this article.

19 Arts. 230-233 and 241, EC Treaty.

20 The now voluminous line of case law on the doctrine of direct effect begins with Case 26/62 Van Gend en Loos [1963] ECR 1. For a discussion of its development see e.g. P. Craig and G. de Burca, European Union Law, 3rd. ed. (Oxford University Press, 2003), chapter 5; new 4th. ed. forthcoming Oxford University Press, August 2007, chapter 8.

21 For the establishment of this doctrine see e.g. Case 6/64 Costa v. ENEL [1964] ECR 585; Case 11/70 Internationale Handelsgesellschaft [1970] ECR 1125; Case 106/77 Amministrazione delle Finanze dello Stato v. Simmenthal SpA [1978] 
premacy of EC law is of particular significance in this regard, which the Court of Justice seems to view as deriving in part from the existence and character of the EU legal system as a distinct legal system:

...the law stemming from the treaty, an independent source of law, could not, because of its special and original nature, be overridden by domestic legal provisions, however framed, without being deprived of its character as community law and without the legal basis of the community itself being called into question. ${ }^{22}$

The transfer by the states from their domestic legal system to the community legal system of the rights and obligations arising under the treaty carries with it a permanent limitation of their sovereign rights, against which a subsequent unilateral act incompatible with the concept of the community cannot prevail... ${ }^{23}$

This view chimes well with certain jurisprudential understandings of the nature of legal systems. There are legal theorists from across the jurisprudential spectrum who contend that a supremacy claim - understood as including a claimed authority to regulate the operation of other normative systems applying to the same subject-community, and the inability to accept any claim to supremacy over the same community made by another legal system - is a necessary feature of legal systems. ${ }^{24}$ The ECJ appears to make

ECR 629, and for its development and reception in Member States see e.g. op. cit n. above, 3rd. edn. ch. 7, forthcoming 4th. edn. chapter 10.

22 Case 6/64 Costa v. ENEL [1964] ECR 585 at 594.

23 Idem.

24 See e. g. Raz, J., Practical Reason and Norms, 2nd. end. (Princeton University Press, 1990), 151-2; Raz, J., The Authority of Law (Clarendon Press, 1979), 118-119; Finnis, J., Natural Law and Natural Rights (Clarendon Press, 1980), at 148-9 \& 267. Recently, however, Andrei Marmor has questioned whether a claim to supremacy truly is a necessary feature of legal systems, in Marmor, A., Positive Law and Objective Values (Clarendon Press, 2001), 39-42. It is perhaps useful to say a word here on the use made in this article of other legal theorist's views on the nature of legal systems. In the present discussion I do not attempt conclusively to 
both of these claims in its operation of the doctrine of the supremacy of EC law, in claiming authority to regulate the operation of Member States legal systems insofar as they conflict with enforceable EC norms, and in resisting claims by some national constitutional courts that ultimate authority to decide the operation of national legal norms vis-⿳亠丷⿵冂vis EC legal norms rests with them. ${ }^{25}$

These doctrines of the primacy and direct effect of EC law $^{26}$ may seem to take us beyond considerations speaking to the existence of a distinct EU legal system into matters regarding the character of its relationship with Member States' legal systems, but they surely also provide evidence of the existence and distinctive character of the EU legal system in the sense of that system possessing its own view on, and criteria as regards, the force and effect of its norms. Moreover, its creation and development of the doctrines of the direct effect and primacy of EC law testify not

establish the truth or falsity of those legal theoretical views in their entirety. Rather, for the most part, I am using aspects of them as an analytical tool to open up some issues regarding the character of and relations between legal systems in the EU, and to assist me in developing my own views regarding those issues. The extent to which I am in agreement with certain of the views of other legal theorists should be apparent from the context, and from my own arguments for or against particular ways of conceptualising the character of the EU legal system and its relations with Member States' legal systems. As the discussion develops, I give particular consideration to aspects of Joseph Raz's views for the reason that Raz is one of the few contemporary legal philosophers who has written extensively on questions specifically pertaining to the nature of legal systems. Such questions seem to have fallen out of jurisprudential fashion to a large extent: it is my hope that the need to properly understand aspects of the EU and other supra-state and international organizations may engender renewed interest in them on the part of legal theorists.

25 See e. g. Case 11/70 Internationale Handelsgesellschaft [1970] ECR 1125. Of course, the ECJs usual modus operandi as regards this issue is to try to avoid an out and out confrontation. Nonetheless, in cases where national courts seem on the verge of contravening the ECJs understanding of the supremacy doctrine, e.g. by possibly reviewing EC norms in light of national constitutional norms, as in the Internationale Handelsgesellschaft litigation, the ECJ rejects such possibilities and firmly re-states its understanding of supremacy, e.g. by making it clear that the validity of EC norms can only be judged by reference to EC law.

26 Other distinctive doctrines regarding the enforceability of EC law and its relationship with national law have emerged in recent years, and some of these will be considered further in section 5 below. 
merely to what the ECJ says regarding the existence of an EU legal system but to what it has managed to do, and to the social reality of the practices it has managed to institute as regards the operation of EU law as a distinct body of law. In having managed to persuade Member States' national courts, albeit sometimes subject to reservations from the point of view of those courts themselves, ${ }^{27}$ to apply and enforce directly effective EC law in national courts, and to accord it primacy over national law in cases of conflict, ${ }^{28}$ and hence allow individuals access to EC rights independently of and sometimes in opposition to, national law, the ECJ has moved beyond talking the talk of the existence and character of a distinct EU legal system to playing a role in ${ }^{29}$ altering the practices of national courts in actually recognising, applying, and granting primacy to some of the norms of that legal system. ${ }^{30}$ As will be discussed further in section 4 below, however, all of this may raise yet more questions regarding the status of EU norms which are directly enforceable in national courts: do they remain primarily norms of the EU legal system but which, for various reasons, happen to be granted domestic enforceability, or do they actually become part of the domestic legal system of a given Member State, such that they are fully part of

27 This is discussed further in section 3.

28 And, more recently, having backed up national courts' obligations to ensure that individuals have proper access to their EC rights by means of the threatened imposition of Member State liability in respect of courts of last instance committing sufficiently serious breaches of EC law established in Case C-224/01 Köbler [2003] ECR I- 10239.

29 I put things this way because, as is often and rightly stressed by commentators in this area, the relationship between the ECJ and national courts, especially in terms of making, receiving, and correctly applying Art. 234 EC Treaty preliminary references is necessarily a co-operative one.

30 See e. g. Factortame Ltd $v$. Secretary of State for Transport (No. 2) [1991] 1 AC 603; Nicolo [1990] 1 CMLR 173; Bundesverfassungsgericht Decision of 7th. June 2000, 2 BvL 1/97. For interesting discussion of how and why national courts have granted EC law supremacy in national courts, see Alter, K., Establishing the Supremacy of European Law, The Making of an International Rule of Law in Europe (Oxford University Press, 2001). 
national law to the extent that national courts have a duty to apply them (or both?)?

All these factors seem to amount to a strong case for understanding the EU legal order as a distinct legal system which exists in addition to the legal systems of its constituent Member States, and with its own criteria determining which norms belong to that system, the manner and extent of their enforceability, and the relations between its own norms and norms of national law with which it interacts in Member States' courts. ${ }^{31}$ In other words, to use the shorthand terminology coined in the introduction to this article, the "27 plus 1" model would seem to have considerable support. One alternative view mentioned in the introduction to this article, that of EU law as merely an aspect of each of the legal systems of the Member States, and not as a distinct entity in addition to those domestic legal systems seems to hold little plausibility. ${ }^{32}$

\section{The Relevance of Rival Supremacy Claims}

If the EU legal system is a distinct legal system in its own right, existing in addition to those legal systems of the EU Member States, what is the relationship between the EU legal system and those national systems of law? Interpreted

31 For further discussions on this point, not all of which accept it without qualification, see Besson, S., "From European Integration to European Integrity: Should European Law Speak with Just One Voice?", 10 European Law Journal (2004), 257-81, at 268-9; Richmond, C., "Preserving the Identity Crisis: Autonomy, System and Sovereignty in European Law", n. above, at 396, and 398-407; Maduro, M., "Contrapunctual Law: Europe's Constitutional Pluralism in Action", in Walker, N. (ed.), Sovereignty in Transition (Hart Publishing 2003), at 504; MacCormick, N., "Liberalism, Nationalism and the Post-Sovereign State", in Bellamy, R. and Castiglione, D. (eds.), Constitutionalism in Transformation: European and Theoretical Perspectives (Blackwell, 1996), 141-155; MacCormick, N., "Juridical Pluralism and the Risk of Constitutional Conflict", in MacCormick, N., Questioning Sovereignty (Oxford University Press, 1999), ch. 7, especially at 105-110. Besson and Richmond in particular go on to offer a modified and more subtle understanding of the character of the EU legal system.

32 However in section 4 I will discuss some considerations which do appear to provide some support for it, and which may cast doubt on some aspects of the view of the EU legal system emerging from the present section. 
in one way, this question has a familiar answer: from the point of view of the EU legal system, certainly as expressed in judgements of the European Court of Justice, EC law has primacy or supremacy over Member States' national law, must prevail over it in cases of conflict, and (under certain conditions ${ }^{33}$ ) can be enforced directly by individuals in national courts. ${ }^{34}$ But if this is so, and if the doctrines of the direct effect and supremacy of EC law over national law answer the question of how to understand the relationship between the EU legal system and Member States' legal systems then, as Neil MacCormick points out, perhaps we have reason to think in terms of there being just a single EU legal system, with the legal systems of its constituent Member States merely as sub-systems operating under the auspices of, and regulated by, that EU legal system:

Once we have established this doctrine of the supremacy of Community law, however, the question inevitably to be posed is whether there is any need at all for an elaborate theory about interaction of distinct systems. If system $X$ enjoys supremacy over system $Y$, why trouble to have a theory about separate systems, rather than a theory which acknowledges the fact that $Y$ belongs to $X$ as sub-system of it?35

However, as MacCormick goes on to discuss in the remainder of this article, and as is also taken up below, there are nonetheless strong reasons for rejecting the "One Big Legal System" model, and they are to be found in the attitudes, pronouncements and practices of some Member States'

33 For discussion of those EC measures which are capable of direct effect, and of the conditions necessary for the doctrine's operation, see e.g. Douglas-Scott, S., Constitutional Law of the European Union (Longman, 2002), part II, chapter 4; Arnull, A. et al., Wyatt and Dashwood's European Union Law, 5th. ed. (Sweet \& Maxwell, 2006), part 3, chapter 5; Craig, P. and Burca, G. de, European Union Law, 3rd. ed., n. above, ch. 5.

34 The seemingly now doomed, at least in its current form, Constitutional Treaty, also includes a primacy clause in Part I, Article I-6.

35 MacCormick, N., "Juridical Pluralism and the Risk of Constitutional Conflict”, n. above, 116 . 
courts, particularly constitutional courts, as regards their view of the relationship between EC law and national law and their reasons for applying EC norms in national courts. As practically every textbook and academic commentator on the subject points out, the issue of the supremacy of EC law is very much a two-sided coin: there is the view of the supremacy of EC law from the point of view of the European Court of Justice on the one hand, and then the differential receptions of that view by national courts in the Member States on the other. ${ }^{36}$ As has already been noted in section 2 above, the ECJ's view is unequivocal: owing to the special nature and purpose of the EC legal order, EC law has primacy over national law in cases of conflict, 37 and this is so whether the national law in question is prior or subsequent to the EC measure, ${ }^{38}$ even as regards potential clashes between EC norms and norms in national constitutions, ${ }^{39}$ and even if this requires significant alterations in past national constitutional practice as regards, for example, whether the judicial suspension and disapplication of primary legislation is legally possible in the jurisdiction in question. ${ }^{40}$ Member States' courts, and especially - where they exist- constitutional courts, vary in their approach both as between Member States and over time. In some jurisdictions the doctrine of the supremacy of EC law over national law has, after troubled beginnings, ${ }^{41}$ in the end been accepted by constitutional courts, but subject to conditions and limitations, such as the EC legal system continuing to

36 Indeed many EU law textbooks divide the issue up this way for pedagogical purposes, see e.g. Craig and Burca, European Union Law, 3rd. ed., n. above, ch. 7; Hartley, T. C., The Foundations of European CommunityLaw, 5th. ed. (Oxford University Press, 2003) chs. 7 and 8.

37 Case 6/64 Costa v. ENEL [1964] ECR 585 at 594.

38 Case 106/77 Amministrazione delle Finanze dello Stato v. Simmenthal SpA [1978] ECR 629, at para. 21.

39 Case 11/70 Internationale Handelsgesellschaft [1970] ECR 1125, at para. 3.

40 Case C-213/89 R $v$. Secretary of State for Transport, ex parte Factortame Ltd. And Others [1990] ECR I-2433.

41 See the "Solange I" decision of the Bundesverfassungsgericht (BVerfG) [1974] 2 CMLR 540. 
guarantee an adequate level of protection of fundamental rights, ${ }^{42}$ and remaining within the proper sphere of its competences, ${ }^{43}$ as is the case in the well documented story of the Bundesverfassungsgericht (BVerfG) in its dealings with the relationship between EC law and German law. ${ }^{44}$ Even in the present more co-operative chapter in this tale, the federal constitutional court and the national constitutional order more broadly has reserved to itself the right to determine whether the EU legal system is continuing to fulfil the conditions that the German constitutional order has imposed. ${ }^{45}$ In the UK, after some years of essentially fudging the issue, ${ }^{46}$ national courts finally had to bite the bullet in the Factortame litigation and grant EC law supremacy over conflicting national law. Although this involved significant changes in national judicial practice as regards the ability of UK courts to suspend and disapply primary legislation, ${ }^{47}$ the House of Lords insisted that this is by reason of and subject to the will of the Westminster Parliament via the European Communities Act 1972.48 The constitutional courts of some Member States which have recently acceded to the EU have also sounded warning signals regarding the fact that they do not accept unequivocally the doctrine of the supremacy of EC law in the terms expressed by the

42 "Solange II' decision of the BVerfG of 22 October 1986, Re. Wünsche Handelsgesellschaft [1987] 3CMLR 225; Bundesverfassungsgericht Decision of 7th. June 2000, 2 BvL 1/97.

43 Brunner $v$. The European Union Treaty [1994] 1 CMLR 57.

44 A similar story can of course be told in respect of several other Member States, e. g. France, Italy, Denmark.

45 For details, see those cases referred to in notes to above.

46 See e. g. Garland v. British Rail [1983] 2 AC 751; Pickstone v. Freemans plc [1989] AC 66; Duke v. GEC Reliance [1988] AC 618; Webb v. EMO [1992] 2 All ER 43; Webb v. EMO (No.2) [1996] 2 CMLR 990.

47 Indeed "revolutionary" changes according to some. For discussion see Wade, W., “Sovereignty - Revolution or Evolution?", 112 Law Quarterly Review (1996), 568; Allan, T., "Parliamentary Sovereignty: Law, Politics and Revolution", 113 Law Buarterly Review (1997), 443.

48 Factortame Ltd. v. Secretary of State for Transport (No. 2) [1991] AC 603, per Lord Bridge. 
ECJ. ${ }^{49}$ What unites these responses is that in each case, the national legal system reserves to itself the right ultimately to determine the relationship between the EU legal system and the national legal system and to impose conditions on the operation of that relationship. Even as they grant EC law supremacy over national law, then, they do so on a different basis from that expounded by the ECJ: for the ECJ, the supremacy of EC law over national law is a consequence of the very nature and purpose of EC law and is hence required as a doctrine of EC law itself, 50 for many national legal systems, EC law has in the end usually been granted supremacy over national law albeit sometimes conditionally, but it has been granted this on the say so, and under the terms set by, the national courts and the national constitutional order more broadly.

If legal theorists such as Raz are correct that a supremacy claim -including a claimed authority to regulate the operation of other normative systems applying to the same subject-community, and the inability to accept any claim to supremacy over the same community made by another legal system - is a necessary feature of legal systems, then this familiar story re. the attitudes of EU Member States' courts should come as no surprise. ${ }^{51}$ Or, to put things another way, on this view of the nature of legal systems, the practices of national courts seem to provide evidence that Member States' legal systems remain just that, distinct legal systems which reserve to themselves the right to determine the operation of other normative systems such as the EU legal system and the relationship between that legal system and domestic law. It is important to note that on

49 See $e . g$. in the case of Poland, the judgement of the Polish Constitutional Tribunal on the constitutionality of the Polish Accession Treaty, Judgement of the 11 th. May 2005 r. in the case K18/04.

50 Case 6/64 Costav. ENEL [1964] ECR 585 at 594. The ECJ realised as early as Van Gend en Loos (Case 26/62 Van Gend en Loos [1963] ECR 1) that it could not allow the effect of EC law to be dependent on the vagaries of national constitutional orders without risking derailing the Community project.

51 See those works cited in $n$. above. 
this understanding, a supremacy claim by a legal system need not come in the form: "my norms trump your norms in all circumstances". Rather, as Raz points out, such a claim can include a permission to another normative system to operate within the jurisdiction of the legal system in question, ${ }^{52}$ and in my view there seems no reason why this could not include a permission for its norms to prevail over that legal system's norms. So long as the permission for another normative system to operate thus is within the grant of the legal system making the supremacy claim, it remains a supremacy claim, and remains a distinct legal system. The attitude of the House of Lords in the UK and Bundesverfassungssgericht in Germany can plausibly be understood in this way: each is granting a permission for the norms of another normative system, the EU legal system, to operate in the domestic system, and to prevail over domestic legal norms in cases of conflict, but each is doing so on the terms set by, and because of a permission granted by, the domestic legal system. Moreover, neither is accepting unequivocally the character and basis of the claim to supremacy made by the European Court of Justice on its own terms. All of this seems to evidence the continued existence of those Member States' legal systems as distinct systems, with distinct supremacy claims (albeit supremacy claims including permissions to another normative system to operate within their jurisdictions, and for the norms of that system to prevail over national norms in cases of conflict), rather than as mere sub-systems of a single EU legal system. ${ }^{53}$

52 Raz, The Authority of Law, n. above, 118.

53 In the literature on this topic there is usually much focus on the more "resistant" Member States, but even in those states whose national constitutional arrangements are extremely open to the reception of EC law and to the doctrine of its supremacy over conflicting national law, it can still be argued that it remains the national legal system which is calling the shots. For example, in the Dutch legal system, wherein international treaties, upon approval by the Dutch Parliament (Netherlands Constitution, Art. 91), become binding domestically (ibidem Art. 93), have precedence over conflicting national law (ibidem, Art. 94), and cannot be reviewed by the courts on grounds of their constitutionality (ibidem, Art. 120), all of 
Two questions seem to trouble commentators writing on this issue: how to conceptualize the situation given these different understandings on the part of the ECJ and of some national courts respectively of who has the ultimate authority to determine the relationship between EC law and national law, and what we should do about it (and indeed whether we should do anything about it), perhaps especially in light of a potential or actual conflict between the ECJ and a national constitutional court over which norms to apply in a given case. On the issue of how to conceptualize the situation, "pluralism" seems to be the order of the day, at least in terms of academic popularity. This means many things to many commentators, 54 but Neil MacCormick's view captures the central idea:

So relations between states inter se and between states and the Community are interactive rather than hierarchical. The legal systems of member-states and their common legal sys-

this is still so because of the terms of the Netherlands constitution, i.e. on the say-so of the Dutch legal system. However, the situation in the Netherlands may be more complex than this, because, as Bruno de Witte notes in his informative article on the topic - Witte, B. de, "Do Not Mention the Word: Sovereignty in Two Europhile Countries: Belgium and the Netherlands", in Walker, N. (ed.), Sovereignty in Transition, n. above, 351-366, at 362-3 - some constitutional scholars in the Netherlands go still further than this and claim that EC law applies and has supremacy in the Dutch legal system not because of the operation of those articles of the Netherlands Constitution referred to above, but on its (i. e. the EC legal system's) own authority. In my view, one can still argue that if this is the attitude of the Dutch courts and Dutch legal system more broadly, then it is still their attitude, and hence the Dutch courts' viewing EC law in this way and allowing it to operate in this way is still happening on their say-so and can still be interpreted as a permission to another normative system to operate within the Netherlands granted by the organs of the Dutch legal system in virtue of their view of the status of certain international legal orders vis-à-vis the Dutch legal system. Resolving this issue would require a foray into Dutch constitutional theory of a kind that cannot be attempted here. If I am wrong and the attitude of the Dutch courts cannot be interpreted as the Dutch legal system granting a permission to the EU legal system to operate, then possibly the Dutch legal system makes no claim to supremacy at all, and, on the Razian view at least, may be a borderline case of a distinct legal system, at least in areas within the competence of the EU.

54 And sometimes many things to the same commentator, see e. g. Neil Walker's discussion of the relations between "explanatory pluralism", "normative pluralism" and "epistemic pluralism" in Walker, N., "The Idea of Constitutional Pluralism”, 65 Modern Law Review (2002), 317-359, especially at 336-339. 
tem of EC law are distinct but interacting systems of law, and hierarchical relationships of validity within criteria of validity proper to distinct systems do not add up to any sort of all-purpose superiority of one system over another. It follows also that the interpretative power of the highest decisionmaking authorities of the different systems must be, as to each system, ultimate. ${ }^{55}$

One thing is clear from the academic literature on this topic: there is a lot of pluralism about. As Nick Barber has noted, in the case of some such accounts, this appears simply to mean that there are a lot of distinct legal systems about in the European Union, ${ }^{56}$ and, in the case of relations between the EU legal system and various Member States legal systems, that neither can be seen as mere subsystems in relation to the other, nor as standing in a hierarchical relation to the other. ${ }^{57}$

As regards what we ought to do as regards the different understandings of the relationship between EC law and national law held by the highest judicial organs of the distinct systems, commentators vary widely in their views. For some the situation amounts to a crisis, to be resolved by tipping the balance in favour of national legal systems, and granting to national constitutional courts the power to limit the

55 MacCormick, "Juridical Pluralism and the Risk of Constitutional Conflict", n. above, at 118 . For other pluralist views see those works referred to in notes and to below.

56 Barber, N., "Legal Pluralism and The European Union", 12 European Law Journal (2006), 306-329, at 325-6. Barber goes on to question whether this is a pluralism sufficiently controversial to be worthy of the name, and postulates his own version of pluralism in which a legal system qualifies as pluralist if there are multiple and inconsistent rules of recognition within a given legal system.

57 As Walker puts it, using a formulation which echoes through the literature on this topic, "The relationship between the orders...is now horizontal rather than vertical - heterarchical rather than hierarchical", Walker, "The Idea of Constitutional Pluralism", n. above, at 337. For a rare non-pluralist reading of the relationship between EC law and national law, see Weyland, I., "The Application of Kelsen's Theory of the Legal System to European Community Law: The Supremacy Puzzle Resolved”, 21 Law and Philosophy (2001), 1-37, especially at 33. 
operation of the doctrine of the supremacy of the EC law. ${ }^{58}$ Others welcome the situation, for example, “...contending that the only acceptable ethic of political responsibility for the new Europe is one that is premised upon mutual recognition and respect between national and supranational authorities". 59 Amongst the welcomers, a plethora of ways forward are envisaged under a variety of titles, including "late sovereignty",60 "contrapunctual law",61 "constitutionalism beyond the state" 62 and "European integrity". 63 Still others counsel caution as regards particular possible ways forward such as whether spelling out a definitive statement of the supremacy principle in a European Constitution is a good course of action. ${ }^{64}$

As was discussed in the opening section, my aim in this article is to work towards a better understanding of relations between legal systems in the EU, not to justify or decry or try to work out what we should do about those relations once we have a better such understanding. In the foregoing discussion, I have argued that there is ample evidence for not conceiving of Member States' legal systems as sub-systems of a single EU legal system, and for viewing those national legal systems as still making claims to supremacy including the claimed authority to regulate the operation of the norms of other normative systems, such as the EU legal system, in domestic courts. In section 2 I also

58 E. g. D. Rossa Phelan, Revolt or Revolution: The Constitutional Boundaries of the European Community (Round Hall/Sweet \& Maxwell 1997).

59 Walker, "The Idea of Constitutional Pluralism", n. above, 337. See also Walker, N., "Late Sovereignty in the European Union", in Walker, N. (ed.), Sovereignty in Transition (Hart Publishing 2003), 3-32 at 4.

60 Walker, "Late Sovereignty in the European Union”, n. above.

61 M. Poiares Maduro, "Contrapunctual Law: Europe's Constitutional Pluralism in Action", in Walker, N. (ed.), Sovereignty in Transition, n. above.

62 Kumm, M., "The Jurisprudence of Constitutional Conflict: Constitutional Supremacy in Europe before and after the Constitutional Treaty”, n. above.

63 Besson, S., "From European Integration to European Integrity: Should European Law Speak with Just One Voice?”, n. above.

64 Craig, P., "Constitutions, Constitutionalism and the EU", 7 European Law Journal (2001), 125- especially at section F - n.b. this was Craig's view in 2001 at any rate. 
surveyed some evidence in favour of understanding the EU legal system as a distinct legal system and not merely as an aspect of each of the Member States' legal systems. Many of the 'pluralist' readings of the relations between the EU legal order and national legal orders also view relations between legal systems of the EU as a series of interactions between distinct legal systems with distinct loci of ultimate authority. ${ }^{65}$ All of this seems to point to a picture in which the answer to the question, 'how many legal systems are there in the EU?', is to be found in the " 27 plus 1 " model, i. e. that there are as many legal systems as there are Member States' legal systems, plus one, the EU legal system, ${ }^{66}$ which is a distinct legal system in its own right, and which has a relationship with each of the Member States' legal systems and, from the point of view of those national systems, the norms of which are granted a permission to operate in domestic systems by national courts under certain conditions. As the discussion in the next section reveals, however, there is countervailing evidence indicating that this picture may be misleading, and that relations between legal systems in the EU are perhaps not all that they thus far seem.

65 Nick Barber is an exception and has a more complex reading of the relations between legal systems in the EU in Barber, "Legal Pluralism and The European Union”, n. above. See further section 4 note.

66 Here I am more or less ignoring the many issues surrounding the present three pillar structure of the EU, e. g. whether "the EU legal system" can be seen as one entity, whether each of the pillars should be seen as sub-systems of some overall EU legal system, with each of those pillar-sub-systems having a different kind of relationship with Member States' legal systems, or whether perhaps only the EC legal order is a legal system properly so called. There is important work to be done in this area but space constraints mean that I cannot attempt this here. For some interesting thoughts on this issue, see Herrmann, C. W., "Much Ado About Pluto? The 'Unity of the Legal Order of the European Union' Revisited”, European University Institute Robert Schumann Centre for Advanced Studies, EUI Working Papers RSCAS 2007/05. See also note above for comment on my use of the term "EU legal system" and "EC law" in the present article. 


\section{Direct Effect And Supremacy: Whose Norms ARE THEY ANYWAY?}

According to the picture which seems to emerge from the discussion so far, Member States' legal systems and the EU legal system are distinct legal systems making distinct supremacy claims. On this understanding, when those legal systems come to interact - for example, when courts in Member States come to apply EC law in a case before them perhaps in opposition to domestic law on a topic- then what is happening is that the Member State legal system in question is granting a permission to the norms of another distinct system, the EU legal system, to operate for now, in a certain way, and under certain conditions, in the domestic legal system, and to have enforceability in domestic courts accordingly. However, this picture is not without its difficulties. We can start to work our way into some interesting puzzles in this regard by examining further the origins and operation of the doctrines of the direct effect and supremacy of EC law.

As every undergraduate student of the subject knows, the direct effect of EC law, that is to say, the direct enforceability in Member States' courts, by individuals, of EC rights and responsibilities ${ }^{67}$ was conclusively established by the ECJ in Van Gend en Loos, with the declaration that: "...according to the spirit, the general scheme and the wording of the Treaty, Article 12 must be interpreted as producing direct effects and creating individual rights which national courts must protect,". 68

In discussions of the legitimacy of this move by the ECJ, much can be made of the Court's relying on the somewhat amorphous "spirit" and "general scheme" of the Treaty in

67 In fact the definition of the doctrine is controversial, see e. g. Craig, P. and Burca, G. de, European Union Law, 3rd. ed., n. above, 178-182 and the literature referred to therein. However, I believe that the definition above will suffice for the purposes of the present discussion.

68 Case 26/62 Van Gend en Loos [1963] ECR 1 at 13. 
justifying its decision. If we look closely, however, at the vision of the community that the ECJ apparently had in mind and/or was trying to realise in this judgement, then a puzzle emerges as regards the status of directly effective EC norms:

The conclusion to be drawn from this is that the Community constitutes a new legal order of international law for the benefit of which the states have limited their sovereign rights, albeit within limited fields, and the subjects of which comprise not only member states but also their nationals. Independently of the legislation of member states, community law therefore not only imposes obligations on individuals but is also intended to confer upon them rights which become part of their legal heritage. 69

In the passage the ECJ makes it clear what -in its view - individuals in Member States stand to gain from the EC (EEC as it then was), especially if it is viewed as a community capable of conferring on them directly effective EC rights, namely that they will become the direct bearers of EC rights which "become part of their legal heritage". This seems somewhat at odds with the picture emerging in previous sections of the EU legal system and Member States' legal systems as distinct systems and with the view that when EC norms are applied in domestic courts, this is, in effect, the domestic legal system granting a permission to the norms of a "foreign" and distinct system to operate domestically under certain conditions. In the famous passage quoted above, in trying to characterise things from the perspective of individuals in Member States' legal systems, the ECJ does not seem to view EC norms as "foreign" norms that will bestow rights on those individuals in their capacity as such, but rather as norms which will become in some sense "theirs" and not remain the norms of a foreign system which happen to be enforceable domestically. Given this 
view, it does not seem too much of a stretch to say that the ECJ could be argued in this passage to be viewing directly effective EC norms as becoming part of the legal heritage of individuals in Member States in the sense of becoming part of the legal doctrine and indeed part of the legal systems of those Member States, and not merely as remaining the norms of another distinct system which, under certain conditions, are enforceable in domestic courts. To return to the shorthand terminology coined in the introduction, on this interpretation, the "Part of Member States' Legal Systems" model is the correct way to think about the relationship between EU law and national law.

This view seems to be confirmed even more clearly in some of the ECJs early statements of the rationale for the doctrine of the supremacy of EC law over national law. In Costa $v$. ENEL, the Court justifies its judgement in part by reference to the distinctive qualities of the entity created by the EEC Treaty: "By contrast with ordinary international treaties, the EEC treaty has created its own legal system which, on the entry into force of the treaty, became an integral part of the legal systems of the member states and which their courts are bound to apply". ${ }^{70}$

Later in the judgement, in discussing the direct effect and supremacy of the then Art. 37 of the EEC Treaty, the ECJ continues:

Such a clearly expressed prohibition which came into force with the treaty throughout the community, and so became an integral part of the legal system of the member states, forms part of the law of those states and directly concerns their nationals, in whose favour it creates individual rights which national courts must protect. ${ }^{71}$

These statements seem to indicate that the ECJ does not view directly effective EC norms merely as the norms of a

70 Case 6/64 Costa v. ENEL [1964] ECR 585 at 593.

71 Ibidem, at 597-8. 
legal system distinct from Member States' legal systems but which is enforceable in those national systems under certain conditions. Rather, it appears to view EC law as being integrated into those systems, and as becoming part of the law of Member States' legal systems. Indeed, when these passages are read in the context of the judgement overall, it is clear that this vision of EC law not as "foreign law" applicable in a domestic system, but as integrated into and part of Member States' own legal systems is, for the ECJ, part of the reason why those national legal systems cannot accord primacy to conflicting "home-grown" norms. ${ }^{72}$

The above approach is confirmed in other of the "classic" supremacy judgements as well:

...in so far as they [directly effective EC norms] are an integral part of, and take precedence in, the legal order applicable in the territory of each of the member states - [those norms] also preclude the valid adoption of new national legislative measures to the extent to which they would be incompatible with community provisions. ${ }^{73}$

AND there are echoes of it in other landmark judgements of the ECJ in which the character of the EC itself is discussed in the course of justifying the decision in question:

It should be borne in mind at the outset that the EEC Treaty has created its own legal system, which is integrated into the legal systems of the Member States and which their courts are bound to apply. The subjects of that legal system are not only the Member States but also their nationals. Just as it imposes burdens on individuals, Community law is also intended to give rise to rights which become part of their legal patrimony. ${ }^{74}$

72 Ibidem, especially at p. 594.

73 Case 106/77 Amministrazione delle Finanze dello Stato v. Simmenthal SpA [1978] ECR 629, at para. 17.

74 Joined Cases C-6/90 \& C-9/90 Francovich and Bonifaci v. Italy [1991]ECR I-5357 at para. 31 . 
All of this seems to confirm the point that, at least according to the ECJ, EC norms are, in terms of their relationship with Member States' legal systems, not merely the norms of a distinct system which are applicable in domestic courts under certain terms and conditions. Rather, the ECJ views at least those EC norms capable of having direct effect in national courts and primacy over national law as actually becoming part of the legal heritage of Member States' nationals, and indeed as becoming part of Member States' legal systems themselves. This indeed seems to shake up the picture which emerged from the discussion in sections 2 and 3 of the EC legal system and Member States' legal systems are distinct but interacting legal systems. However, elements of that picture, such as the claims to supremacy made in respect of the EC legal system by the ECJ, and in respect of Member States' legal systems by national constitutional courts still seem well supported by the evidence discussed above. Can we accept all of this together, or does something have to give? Do the claims to supremacy by both the EC legal system and national legal systems pull in one direction - that of there being distinct systems with distinct sets of norms wherein sometimes the norms of one system are given permission to operate in another system - but the statements above by the ECJ re. the status of directly effective EC norms as actually becoming part of national law pull in another? However we think about this, we seem now to have a more complex picture emerging wherein directly effective EC norms are part of a distinct legal system, the EU legal system, but can also in some sense be seen as part of the legal systems of Member States and part of the domestic legal heritage of individuals in Member States. Are such norms part of a distinct EU legal system, and part of Member States' legal systems at the same time? Whose norms are they anyway?

One way forward in this regard might be not to rely so exclusively on what the ECJ has said on the topic. For starters, it might be thought that there is a tension in the ECJ's 
understanding of the situation because, as was discussed in section 2 above, on the one hand the Court insists that EU law forms a distinct and independent legal system, but on the other hand, those statements examined above reveal that sometimes it seems to view EU law as actually part of Member States law. ${ }^{75}$ Moreover, the Court, of course, has its own reasons for presenting things in one way or another at one point or another, and perhaps it is easier to persuade Member States' courts to apply EC law and give it precedence over conflicting national law if you first of all present that EC law to them as, in some sense, part of their own legal heritage, and part of their own legal systems. The issues under discussion in this section relate to how we determine what are the limits of legal systems, and to whether there is a correct way to understand where one legal system leaves off and another begins. Considerable legal theoretical attention has been given to such questions by Joseph Raz both in his work on the nature of legal systems ${ }^{76}$ and, more recently, in work on the so-called inclusive vs. exclusive legal positivism debate. ${ }^{77}$ Some of the distinctions and considerations which Raz discusses may be of use here in better focussing these questions with regard to the relationship between the EU legal system and Member States legal systems.

In discussing the issue of how we identify which norms belong to a given legal system, i.e. the criteria of membership of that system, Raz takes the approach that the starting point in this regard is that a legal system consists of all those norms which its "primary norm-applying organs"78

75 If the correct understanding of the situation is that EU norms are simultaneously part of a distinct EU legal system and a constituent part of Member States' legal systems, which hence have an overlap in content with the EU legal system, then the tension will be resolved somewhat. This possibility is mentioned further towards the end of this section.

76 Raz, J., The Concept of a Legal System, 2nd. ed. (Clarendon Press 1980), especially chs., VIII, IX and the "Postscript" to that work; Raz, J., The Authority of Law, n. above, chs. 5 and 6.

77 Raz, J., “Incorporation by Law", 10 Legal Theory (2004), 1-17.

78 Raz, J., The Authority of Law, n. above, 109. 
- such as courts, tribunals, and other judicial bodies- are under a duty to apply. ${ }^{79}$ However, he contends that such a criterion needs to be modified in order to give a complete answer to the question of which norms belong to a given legal system because, amongst other things, 80 not all norms which the courts of a given legal system are under an obligation to apply thereby become part of the legal system in question:

Quite often the courts have an obligation to apply laws of other legal systems, rules of private associations, and so on, although these were not and do not become part of the legal system. ${ }^{81}$

US and UK statutes give legal effect to company regulations, to university statutes, and to many other standards without thereby making them part of the law of the United Kingdom or United States. Conflict-of-law doctrines give effect to foreign law without making it part of the law of the land. Such references make the application of the standards referred to legally required, and rights and duties according to law include thereafter rights and duties determined by those standards. But they do not make those standards part of the law. They no more become part of the law of the land than do legally binding contracts, which are also binding according to law and change people's rights and duties without being themselves part of the law of the land. ${ }^{82}$

In these passages, Raz is drawing a distinction between norms which are binding according to a given legal system and hence given legal effect by the courts of that system on

79 Raz discusses his reasons for taking as his focus norm-applying institutions such as courts rather than norm-creating institutions such as legislatures in Raz, The Concept of a Legal System, n. above, ch. VIII, especially at 189-197; The Authority of Law, n. above, ch. 5 especially at 87-88.

80 Other complications in correctly determining the identity of legal systems are discussed by Raz in the works referred to in notes and above.

81 Raz, The Authority of Law, n. above, 119. See also ibid. at 97, 102, 120.

82 Raz, "Incorporation by Law", n. above, at 10. 
the one hand, and norms which are actually part of the legal system of a given jurisdiction on the other. This distinction can be used to illuminate the rival pictures of the relationship between the EU legal system and Member States' legal systems considered in this article so far. If we adhere to the view which seemed to emerge from the discussion in sections 2 and 3 above, i.e. that the legal order of the EU and Member States' legal orders are distinct legal systems wherein what happens when a court in a Member State enforces an EU norm domestically is that the Member State legal system grants a permission to the norms of another system to operate within the national system on certain conditions, then, to put things in Razian terms, this seems to be a case of a legal system giving legal effect to certain norms (in this case, EC norms) but without those norms thereby becoming part of the legal system in question. On the other hand, if we take seriously the ECJ's view, discussed earlier in the present section, that EC norms capable of primacy and direct effect actually become in some sense part of the legal heritage of Member State nationals and indeed part of the law of those Member States, then on this interpretation of the relationship between EC law and national law, EC norms overstep the "binding according to/given legal effect by legal system X" side of the Razian distinction and actually become part of Member States' legal systems.

But which interpretation should we adopt? One tempting avenue in this regard might be to examine the terms of measures which govern the relationship between EC law and national law in national courts, for example, in the case of the United Kingdom, the European Communities Act 1972. As was noted in the discussion in section 3 however, the English courts have varied in their understanding of what that statute requires of them over time, ${ }^{83}$ and the terms of it are not entirely perspicuous on the matter of whether EC law is to be regarded as part of English law or

83 See notes to above. 
merely binding according to and hence to be given legal effect by it. ${ }^{84}$ Section 2(1) of the Act tells us that:

All such rights, powers, liabilities, obligations and restrictions from time to time created or arising by or under the Treaties, and all such remedies and procedures from time to time provided for by or under the Treaties, as in accordance with the Treaties are without further enactment to be given legal effect or used in the United Kingdom shall be recognised and available in law, and be enforced, allowed and followed accordingly; and the expression "enforceable Community right" and similar expressions shall be read as referring to one to which this subsection applies. 85

But this does not seem particularly helpful as regards whether we should regards such domestically enforceable Community norms as merely being given legal effect by the legal systems in the UK, or rather as actually becoming part of those systems. Even if we were minded to offer a close reading of this provision, it would seem we can find evidence supporting each of these views, e. $g$. the "to be given legal effect" formulation sounds closer to the idea of EC norms as the norms of a distinct system merely being binding according to domestic law, but the "shall be recognised and available in law" part seeming to support an interpretation to the effect that those norms actually become part of that domestic law.

The evidence from the UK incorporating measure hence seems somewhat inconclusive. Moreover, if we go down this route, then it may turn out that there are as many interpretations of whether EC norms are merely given legal effect by, or rather become part of, Member States' legal systems as there are different approaches to that question in Member States' national constitutional law and in their respec-

84 I refer to the English and not UK law in order to avoid the complications which arise from the fact that the UK is arguably a multi-legal system state, see n. above.

85 European Communities Act 1972, s2(1). 
tive incorporating measures, if indeed their constitutional order requires such measures. This, of course, is one of the factors motivating the ECJ to try to settle issues such as the primacy and direct effect of EC law centrally, and to claim that such doctrines do not rest on their acceptance by or incorporation into Member States' national law, but rather stem from the nature and purpose of the EC itself. ${ }^{86}$ Given that this is so, even if we can identify a coherent view in the relevant incorporating measure or incorporating practice re. whether EC norms are merely given legal effect by or rather become part of national law, why should we privilege the point of view of the Member States' legal systems on this issue rather than the view of the ECJ?

Raz himself is suspicious of the idea that this issue can be settled purely by looking to the technical means of incorporation or the language of the incorporating measure. ${ }^{87}$ Rather, he claims, “...it depends in part on our general conception of what a legal system is and how it relates to normative standards outside it, such as foreign law, moral considerations, or the constitution and laws of nonstate organisations". 88

What sort of factors does he view as relevant in this regard? In earlier work on this topic, Raz puts the matter as follows:

The reasons for enforcing the norm, and the attitude of the courts and the legislature to its enforcement, are the crucial factors...Ultimately the problem turns on an accumulation of evidence justifying a judgement whether a norm is enforced on the grounds that it is part of the law's function to support other social systems or because it is part of the law itself. 89

86 In e.g. Case 26/62 Van Gend en Loos [1963] ECR; Case 6/64 Costa v. ENEL [1964] ECR 585; Case 11/70 Internationale Handelsgesellschaft [1970] ECR 1125.

87 Raz, The Authority of Law, n. above, 119-120; Raz, "Incorporation by Law", n. above, 11-12.

88 Raz, "Incorporation by Law", n. above, 12.

89 Raz, The Authority of Law, n. above, 102. 
And in the more recent, 'Incorporation by Law', he explains the importance of the distinction between norms given legal effect to by a given legal system and norms which are part of that legal system as follows:

...so long as the law maintains its place at the heart of the political organization of society and remains a focus of attitudes of identification and alienation, the distinction has an importance way beyond any legal technicalities. ${ }^{90}$

It [the law] is a political institution of great importance to the working of societies and to their members. From this point of view a British person cannot say "Polish law is my law" just because it will be followed by British courts when their conflict-of-law rules direct them to do so. The distinction between standards that the courts have to apply and those that are the law of the land is vital to our ability to identify the law as the political institution that it is. ${ }^{91}$

All of this suggests some intriguing possible ways forward as regards examining whether EC norms should be viewed as the norms of a distinct system of law which are merely given legal effect, for now, and under certain conditions, in Member States' legal systems, or whether those norms have become part of the law of Member States' legal systems. If Raz is correct about the distinction he draws and the reasons for drawing it, 92 then in order to investigate this issue more fully, we will need to inquire into, amongst other things, the reasons why Member States' courts do enforce and grant primacy to EC law, and the attitudes, including attitudes of identification with and/or alienation from EC law, on the part of those courts, and of EU citizens. Do English courts apply and enforce EC law because of some

90 Raz, "Incorporation by Law", n. above, 12.

91 Ibidem, 15.

92 See note above for the use made of the views of other legal theorists in this article, and see the same note, and section 1 above, for the aims of the discussion overall. 
belief that it is valuable to support and give effect to the norms of a normative system distinct from their domestic legal system or are they enforcing it as "their own" law, perhaps motivated by a sense of identification with character and purposes of the polity that is the EU and of which they are a constituent part? ${ }^{93}$ Do Member States' nationals/EU citizens, in considering and/or seeking to rely on EC law in national courts think, "EU law is my law"?94 One obvious answer would be that it depends on who you ask and it depends which area of EU law you mean, but what is useful in considering the above issues is that they may point the way towards some of the questions that it would be worth asking, and of whom it would be worth asking them, if we are to gain a more nuanced view of the limits of and relations between legal systems in the EU. We could also ask some of these questions not merely of Member States' courts and nationals but also of the ECJ itself. Is it mere rhetoric when the ECJ refers to EC norms capable of supremacy and direct effect as already "part of" the law of Member States, or does the Court really view such a status as contributing to the reasons for the doctrine of primacy? Would it represent the abnegation of the distinctiveness of the EC as a "new legal order" 95 to view EC law as fully part

93 In considering these issues it would be necessary to revisit the "standard" understanding of national courts as enforcing EU law, but only on the say so, and under the terms specified by, the national legal system, discussed in section 3 above. Perhaps attitudes towards EU law and reasons for enforcing it on the part of national courts are more varied and complex than the discussion in section 3 indicated.

94 Will the answer be different depending on whether they are asked the question qua Member State national or qua EU citizen? Is it even sensible to draw such a distinction when a point of EU law is at issue? From the point of view of the EU itself, the very creation of EU citizenship and the development of its status arguably has as one of its aims the encouragement of just this "EU law is my law" way of thinking. In my view, this is an avenue clearly worthy of future investigation as regards the issue of the status of EC norms in national legal systems. For discussion of some recent developments which might be relevant to such an investigation, see S. Wernicke, "Au nom de qui? The European Court of Justice between Member States, Civil Society and Union Citizens”, 13 European Law Journal (2007), 380-407.

95 Case 26/62 Van Gend en Loos [1963] ECR 1 at 12. 
of Member States' legal systems rather than as a legal system distinct from them whose norms are granted a permission to operate domestically? Or would it perhaps be the ultimate indication of the flourishing of the EU legal order and of its successful integration into Member States' legal systems to view it as fully part of their law rather than as a legal system distinct from them but binding according to them? Of course, as was briefly mentioned earlier in this section, perhaps the "rather than" is out of place here, and it is possible that EC norms enforceable in national courts are part of a distinct EU legal system and part of Member States' legal systems at the same time. If this is the case, then the simple picture of there being as many distinct legal systems in the EU as there are member states' legal systems plus one, the EU legal system which has a separate relationship with each of the legal systems of the Member States again seems to break down somewhat, because when we come to examine which norms belong to which system, we will find considerable overlap in content between the EU legal system and Member States' legal systems simply in virtue of EU norms being applied by national courts. On this view, when a national court applies an EC norm domestically, it thereby renders that EC norm part of the Member State legal system as well as part of the EU legal system, and hence increases the overlap between the domestic system and the EU legal system. ${ }^{96}$

Things are complicated even further in terms of considering which norms belong to which legal system -Member State or EU- if we adopt Raz's method of understanding the criteria of legal system membership in terms of those norms which the legal system's primary norm-applying organs - such as courts, tribunals and other judicial bodiesare obligated to apply. If we apply such a view to the EU le-

96 A similar point is made by Nick Barber in "Legal Pluralism and The European Union", n. above, at 326-7. Barber regards what I describe as the "simple picture" as inadequate accordingly, and puts forward as plausible the view that, "To begin with, there were two, clearly distinct, legal systems.... Over time they have moved together, the boundaries of each becoming blurred" (ibidem at 326). 
gal system itself, further complexities about which norms belong to which system emerge because for the purposes of much of the application of EU law, the relevant courts are actually the domestic courts of Member States' legal systems. Although the ECJ claims to retain an interpretive monopoly as regards the meaning and application of EC law, ${ }^{97}$ and although there are actions in EU law which take place specifically in the ECJ or Court of First Instance, 98 it is, famously, national courts who do the lion's share of the application and enforcement of EC law given the terms of operation of the EC Treaty Art. 234 preliminary reference procedure, and the creation by the ECJ of doctrines such as the direct effect and supremacy of EC law $^{99}$ and the principle of Member State liability. This seems to indicate that, when a point of EC law is in play and must be applied by national courts, that those national courts are in effect acting as EC courts, and as part of the EC legal system. 100 Given this level of overlap as regards system norms and indeed system institutions, we may begin to wonder whether it is sensible even to continue to ask questions regarding which norms belong to which system -Member State or EU- although once again, the points mentioned above

97 EC Treaty, Art 220. This is, of course, subject to the provisions governing the jurisdiction and operation of the Court of First Instance and its relationship with the ECJ: EC Treaty Arts. 220-225.

98 E. g. judicial review of EC measures under EC Treaty Art. 230, actions re. the non-contractual liability of the EC under EC Treaty Arts. 235 and 288, and enforcement actions against Member States under EC Treaty Arts. 226-228.

99 And other doctrines relevant to the enforcement of EC law by individuals in national courts mentioned in section 5 below.

100 This point is made by many commentators, see e. g. Sweet, A. Stone \& Brunell, T., "Constructing a Supranational Constitution", in Sweet, A. Stone, The Judicial Construction of Europe (Oxford University Press 2004), at 97; Barber, "Legal Pluralism and The European Union", n. above, at note 94; Craig and Burca de, European Union Law, 3rd. ed., n. above, 433. For further discussion of the relationship between the ECJ and national courts, and of the role of national courts in applying and enforcing EU law, see e. g. Cohen, Jeffrey, "The European Preliminary Reference and US Supreme Court Review of State Court Judgements: a study in comparative judicial federalism" (1996) 44 American Journal of Comparative Law, 421-461; Weatherill, S., Law and Integration in the European Union, 107-116; Alter, K., Establishing the Supremacy of European Law, The Making of an International Rule of Law in Europe n. above. 
raised by Raz's work on the nature and limits of legal systems suggest that interesting questions remain in this regard, which can be solved only by focussing on various of the attitudes to these systems in terms of their role as part of units of political identification and/or alienation held by, amongst others, Member States' courts and Member States nationals/EU citizens.

\section{Conclusion And Future Issues: Further Complexities AND RECENT DEVELOPMENTS IN THE RELATIONSHIP BetweEn THE EU LEGAL System AND MEMber STATES LEGAL Systems}

In following the foregoing discussion the reader may well feel more frustration than enlightenment for it may feel as if I have raised many questions and provided answers to few of them. What I have tried to do is to consider some of the evidence for the " 27 plus 1" model, i.e. for regarding the EU legal system and Member States' legal systems as distinct but interacting systems wherein the application of EC norms in national courts amounts to the national system in question granting the norms of a distinct system permission to operate domestically under certain conditions. Having established the prima facie plausibility of this picture, I sought to introduce some further considerations which undermine and complicate it, such as the possibility that EC norms which are directly enforceable in national courts are best interpreted as actually becoming part of the national legal system in question, and hence that the "Part of Member States' Legal Systems" model is the correct one. With these tensions on the table, I then considered some work on the nature of legal systems from general jurisprudence which may point the way to some further investigations capable of resolving or at least shedding further light on these tensions. It is true that in all of this I have not staked my claim to a conclusive position on the matter of the character of and relations between legal systems in the EU, but as 
I stated at the outset, my aim in the present discussion is rather to provide a better and more focussed understanding of the relevant questions and puzzles as regards this issue by examining them in light of some legal philosophical considerations.

Even in the course of attempting to focus the relevant issues, more such puzzles reveal themselves. The discussion in section 4 above focuses primarily on some puzzles generated by the status of directly effective EC law capable of directly substituting itself for conflicting national law in a manner which may justify interpreting it as actually becoming part of the law of the Member State legal system in question. However, not all EC measures are capable of such effects, perhaps most famously, EC directives are not capable of them in so-called "horizontal" situations, that is, when being enforced against, and hence imposing obligations on, individuals rather than on emanations of the state in the Member State in question. ${ }^{101}$ It has been suggested to me ${ }^{102}$ that perhaps one reason ${ }^{103}$ why EC directives cannot be enforced in national courts in "horizontal" situations is that they are best interpreted as the norms of another legal system distinct from that of the Member State system in question and that, in the absence of national implementing measures envisaged to translate them into national law ${ }^{104}$ they remain thus, and hence unenforceable in national courts. ${ }^{105}$ One intriguing possibility generated if we adopt

101 See e.g. Case 152/84 Marshall [1986] ECR 723; Case C-188/89 Foster $v$ British Gas [1990] ECR I-3133; Case C-91/92 Dori [1994] ECR I-3325; Case C-443/98, Unilever Italia SpA v. Central Food SpA [2000] ECR I-7535 at para. 50.

102 By Jan Komárek, DPhil candidate, Somerville College, Oxford. I hope I have conveyed the point as made to me accurately.

103 The ECJ itself, as well as commentators in this area, have flirted with many possible reasons and explanations for the horizontal/vertical distinction as regards the domestic enforceability of directives.. For a discussion and attempted refutation of some of the most popular arguments, see the Opinion of Advocate-General Lenz in Case C-91/92 Dori [1994] ECR I-3325-

104 EC Treaty, Art. 249.

105 This, though, still leaves the puzzle of how the same norms of another distinct system, if that is what they are, can be part of or at least given legal effect in the national legal system for the purposes of a vertical relationship. Also cf. S. 
the Razian line on criteria of legal system membership is that, as regards enforceability by individuals against other individuals in the absence of national implementing measures, EC directives may not be part of the EU legal system either, because according to the ECJs own case law on the topic, national courts are not under an obligation to apply them in the sense of directly enforcing them in cases where they are being used to impose obligations on individuals. This leaves us with quite a puzzle, as clearly such directives exist in EU law in the sense that they are enacted by EU institutions, and are enforceable by national courts in socalled "vertical" situations, i. e. as against emanations of the state in question. ${ }^{106}$ Are directives, then, to be regarded as part of the EU legal system only to the extent they are directly enforceable in national courts, $i$. $e$. only in vertical situations and not in horizontal ones? What sort of picture of a legal system would that entail?

As if this were not puzzling enough, questions also surround how we should understand the status of EC norms which have some kind of "non-direct-effect" effect in national legal systems according to some of the more recently developed doctrines of the ECJ. It has long been possible for EC norms, even if they are not capable of direct effect, to generate an "indirect effect" or interpretive effect in national law, in the sense that such national law has to be interpreted "as far as possible" in line with the EC norm in question. ${ }^{107}$ In some cases this has been very far indeed, requiring the national court to, "do whatever lies within its jurisdiction, having regard to the whole body of rules of national law, to ensure that [the relevant directive] is fully ef-

Prechal who contends that directives become part of the legal systems of Member States immediately upon the date of their entry into force, in Prechal, S., Directives in EC Law, 2nd. ed., (Oxford University Press, 2005), at 93.

106 Subject to them meeting the other conditions necessary for the direct effect of EC norns, as developed by the ECJ in Case 26/62 Van Gend en Loos [1963] ECR 1 and subsequent cases.

107 See e. g. Case 14/83 Von Colson [1984] ECR 1891; Case C-106/89 Marleasing [1990] ECR I-4135; Case C-456/98 Centrosteel v. Adipol [2000] ECR I-6007. 
fective...”. ${ }^{108}$ Are EC directives exerting such a strong interpretive effect in national law part solely of the EU legal system or are they also, in some sense, "part of" the national system as well, albeit not part of it in the sense of being capable of substituting themselves into national law in place of a conflicting national norm? ${ }^{109}$ Even if it is not appropriate to view them as part of the national system in themselves, they are clearly capable of changing the interpretation and effect of norms in the national system, and are hence given some kind of legal effect in the national system in question. Exactly what status do non-directly-effective directives exerting a strong interpretive influence over, and hence altering the reading of, national norms have in national legal systems?

Moreover, in more recent case law, directives not themselves capable of generating rights to be relied on directly by individuals in national courts have, even in cases against other individuals, been held by the ECJ to generate some kind of "incidental" or "exclusionary" effect vis á vis national norms, sometimes rendering those national norms unenforceable as against individuals. A now (in?)famous example of this is found in Unilever $v$. Central Food. ${ }^{110}$ In this case, an otherwise valid Italian national law specifying certain labelling requirements was, according to the ECJ, rendered unenforceable against an individual in a national court action on the grounds that the relevant Member State had adopted the national law in breach of a "standstill" clause in an EC directive ${ }^{111}$ requiring that such national

19foined cases C-397/01 to C-403/01, Pfeiffer and others $v$. Deutsches Rotes Kreuz [2004] ECR I-8835, at para. 118.

109 For discussion of the relevance of the concept of substitution in understanding the case law on indirect effect, and on incidental or exclusionary effect, see, Pablo V. Figueroa Regueiro, "Invocability of Substitution and Invocability of Exclusion: Bringing Legal Realism to the Current Developments of the Case-Law of "Horizontal" Direct Effect of Directives", Jean Monnet Working Papers, Jean Monnet Center for International and Regional Economic Law and Justice, http://www. jeanmonnetprogram.org/papers/02/020701.html.

110 Case C-443/98, Unilever Italia SpA v. Central Food SpA [2000] ECR I - 7535.

111 Directive 83/189 in this case. 
laws be notified to the Commission and then a waiting period observed prior to their adoption, in order that the Commission could check their conformity with EC measures regarding the free movement of goods. As is often emphasized by commentators in this area, as well as by the ECJ itself, 112 this is not an example of direct effect as there are no rights in the "procedural" EC directive imposing the notification and waiting period obligations on the Member State for individuals to rely on. For all that, however, the EC directive in question exerts a significant influence in national law, with important consequences for, for example, contractual relations between individuals contracting under national law, by excluding or rendering unenforceable as against individuals national laws which do not conform to its procedural requirements. To which legal system(s) do these kinds of EC directives belong? They are clearly enforceable in some sense in national proceedings and hence given some kind of legal effect in national law. But it is a somewhat strange kind of legal effect, for they function not so as to give individuals access to rights enshrined in the EC measure in question, but rather merely to knock out of play in the present legal proceedings an otherwise valid national law. Is it perhaps even possible that the relevant EC directive in such cases forms "part of" national law, albeit in a negative sense by rendering unenforceable otherwise applicable national norms not in conformity with it? Can a norm be "part of" a given legal system in some sense by its being used to knock out of play an otherwise applicable national norm? The ECJ has been criticized for persisting with this "incidental effect" line of case law ${ }^{113}$ but it clearly pro-

112 Case C-443/98, Unilever Italia SpA v. Central Food SpA [2000] ECR I - 7535 at paras. 50-51.

113 Including by its own Advocates-General, see e.g. A-G Jacobs in Case C-443/98, Unilever Italia SpA v. Central Food SpA [2000] ECR I - 7535. For further discussion see also A. Arnull, 'Editorial: The incidental effect of directives', 24 European Law Review (1999), 1; Dougan, M., "The "disguised" vertical direct effect of directives?”, 59 Cambridge Law Journal (2000), 586; “Editorial Comments: 'Horizontal direct effect - A law of diminishing coherence?" 43 Common Market Law Review (2006), 1-8. 
vides fertile ground for examining some further issues re. the relations between legal norms and legal systems in the European Union!114

Investigating such issues further, in the service of developing a more conclusive view on the correct way to understand the character of and relations between legal systems in the EU, is a task which I hope to take up in future work on this topic. For now, I hope that I have succeeded in bringing some of the relevant issues better into focus, and in using legal philosophical insights to bring to life some of the fascinating puzzles regarding legal systems and their interaction which European Union law reveals.

114 Other recent developments, such as whatever doctrine or at any rate legal point the ECJ was seeking to establish in Case C-144/04 Mangold v. Helm [2005] ECR I-9981 are also worthy of further consideration in this regard. For critical comment on this development see 'Editorial Comments: 'Horizontal direct effect - A law of diminishing coherence?" n. above; Editorial, 'Out with the old...' (2006) 31 European Law Review (2006), 1. 